\title{
Rancang Bangun Sistem Informasi Digital Layanan Administrasi Publik Desa Berbasis WEB Responsive
}

\author{
Ahmadi $^{1)}$, Hengki Juliansa ${ }^{2}$ \\ ${ }^{1)}$ Manajemen Informatika, STMIK Bina Nusantara Jaya Lubuklinggau \\ ${ }^{2)}$ Sistem Informasi,STMIK Bina Nusantara Jaya Lubuklinggau \\ Jl. Yos Sudarso No. 97 A Kel Jawa Kanan Kota Lubuklinggau \\ Email : ahmadi.bnj@gmail.com ${ }^{1)}, \underline{\text { hengki.juliansa@gmail.com }}{ }^{2)}$
}

\begin{abstract}
Public services in all forms of service activities carried out by central agencies, regions and the environment of stateowned or regional business entities in the form of goods and or services can be said to be obligations that must be carried out by public service providers in accordance with statutory provisions. The form of service provided by public service providers is certainly still much that must be addressed and carried out evaluations certainly aim to improve the quality of public services to the public. The process of public administration services in the village of Tanjung Kecamatan Muara Kelingi, Musi Rawas Regency was carried out based on community visits to the village office, then data collection of population identities, recording community needs for the desired administrative services and following up on community needs so that the process took time and cost. From these problems, it is necessary to build a digital information system that is responsive web-based public administration service where the community can process the application for making a statement from the village through the system and the community can also obtain certificates printed through digital information systems after the proposal is validated and approved by the village head. So as to provide convenience for the village community in getting the desired cover letter.
\end{abstract}

Keywords : SDLC, public services, administration, responsive web

\begin{abstract}
ABSTRAK
Pelayanan publik segala bentuk kegiatan pelayanan yang dilakukan oleh instansi pusat, daerah dan lingkungan badan usaha milik Negara atau daerah dalam bentuk barang dan atau jasa hal ini dapat dikatakan sebagai kewajiban yang harus dilakukan oleh lembaga penyedia pelayanan publik sesuai dengan ketentuan peraturan perundang-undangan. Bentuk pelayanan yang diberikan oleh penyedia pelayanan publik tentunya masih banyak yang harus dibenahi dan dilakukan evaluasi tentunya bertujuan untuk meningkatan kualitas layanan publik kepada masyarakat. Proses pelayanan administrasi publik didesa Tanjung Kecamatan Muara Kelingi Kabupaten Musi Rawas dilakukan berdasarkan kunjungan yang dilakukan masyarakat ke kantor desa, kemudian pendataan identitas penduduk, mencatat keperluan masyarakat terhadap layanan administrasi yang diinginkan dan menindaklanjuti kebutuhan masyarakat untuk diketahui oleh kepada desa sehingga dari proses tersebut membutuhkan waktu dan biaya. Dari permasalahan tersebut maka perlu dibangun suatu sistem informasi digital layanan administrasi publik berbasis web responsive yang mana masyarakat dapat melakukan proses permohonan usulan pembuatan surat keterangan dari desa melalui sistem dan masyarakat juga dapat memperoleh surat keterangan yang dicetak melalui sistem informasi digital setelah usulan divalidasi dan disetujui oleh kepala desa. Sehingga memberikan kemudahan bagi masyarakat desa dalam mendapatkan surat pengantar yang diinginkan.
\end{abstract}

Kata kunci : SDLC, pelayanan publik, administrasi, web responsive 


\section{Pendahuluan}

Perkembangan zaman yang semakin canggih, dan dengan meningkatnya ilmu pengetahuan dan teknologi sangat jelas mempengaruhi kehidupan masyarakat secara luas serta mendorong manusia untuk melakukan aktifitas dengan cara-cara yang mudah, efektif, dan efisien. Peran teknologi sekarang ini sudah dapat dikatakan sangat membantu aktifitas manusia dalam melaksanakan kegiatan kesehariannya, baik dibidang politik, pendidikan, bisnis, serta dibidang- bidang lainnya. Website merupakan kumpulan-kumpulan halaman web yang di dalamnya terdapat sebuah domain mengandung informasi (Tofik \& Hartawan, 2017).

Internet adalah sistem global jaringan komputer yang saling berhubungan yang menggunakan standar Internet Protocol Suite (TCP/IP) untuk melayani miliaran pengguna di seluruh dunia. Internet membawa berbagai macam sumber informasi dan layanan, seperti antarlinked hypertext dokumen dari World Wide Web (WWW) dan infrastruktur untuk mendukung surat elektronik (Nurmanina, Riska, \& Harihanto, 2013). Internet merupakan media jaringan komunikasi yang sudah tidak asing lagi di kalangan masyarakat karena sudah menjadi kebutuhan bagi setiap orang. Sebagai perangkat komunikasi, internet memberikan kemudahan bagi masyarakat dalam mencari informasi dan pengembangan ilmu pengetahuan.

Website (Situs Web) merupakan kumpulan dari halaman-halaman web yang berhubungan dengan filefile lain yang terkait. Dalam sebuah website terdapat suatu halaman yang dikenal dengan sebutan home page. Home page adalah sebuah halaman yang pertama kali dilihat ketika seseorang mengunjungi website. Dari home page, pengujung dapat mengklik hyperlink untuk pindah kehalaman lain pada website tersebut (Hendrianto, 2014). Melalui pemanfaatan jaringan internet dapat dilakukan pengembangan aplikasi dengan teknologi berbasis Responsive Web Design (RWD). Responsive Desain merupakan sebuah pembangunan website dengan menempilkan design yang elegan dengan ukuran yang sesuai pada tiap device yang ditampilkan (Novianty, 2017). Dengan metode ini, web akan beradaptasi jika dibuka dari perangkat mobile berukuran kecil maupun perangkat komputer desktop dengan ukuran monitor besar. Ukuran huruf, user interface, gambar dan tata letak akan menyesuaikan dengan lebar layar dan resolusi layar monitor yang tersedia. Hasilnya pengguna akan merasakan pengalaman mudah membaca, nyaman dan melihat informasi web tersebut sama dengan jika ia melihat melalui perangkat komputer meja.

Pelayanan publik merupakan pemberian layanan (melayani) keperluan masyarakat yang mempunyai kepentingan pada organisasi itu sesuai dengan aturan pokok dan tata cara yang telah ditetapkan (Alandari, 2013). Dalam undang-undang nomor 25 tahun 2009 tentang pelayanan publik merupakan kegiatan atau rangkaian dalam rangka pemenuhan kebutuhan pelayanan sesuai dengan peraturan perundang-undangan bagi setiap warga negara dan penduduk atas barang, jasa dan/atau pelayanan administrastif yang disediakan oleh penyelenggara pelayanan publik (Sari, 2016). Sedangkan Pelayanan merupakan suatu kegiatan atau urutan kegiatan yang terjadi dalam interaksi langsung antara seseorang dengan orang lain atau mesin secara fisik, dan menyediakan kepuasan pelanggan (Sugiyarto \& Irawan, 2013).

Sistem informasi adalah sekumpulan prosedur organisai yang dilaksanakan untuk mencapai suatu tujuan yaitu menberikan informasi bagi pengambil keputusan dan untuk mengendalikan organisasi (Wijaya, 2015). Sistem informasi disini berupa sistem pelayanan administratif. Pelayanan administratif adalah pelayanan berupa penyediaan berbagai bentuk dokumen yang diperlukan oleh publik, misalnya : Pembuatan Kartu Tanda Penduduk (KTP), Sertifikat Tanah, Akta Kelahiran, Akta Kematian, Buku Kepemilikan Kendaraan Bermotor (BPKB), Surat Tanda Nomor Kendaraan (STNK), Izin Mendirikan Bangunan (IMB), Paspor, dan sebagainya (Arsyad \& Sodiq, 2014).

Dalam permasalahan layanan administrasi publik yang biasanya membutuhkan waktu beberapa hari atau bahkan beberapa minggu, penggunaan Sistem Pelayanan Administrasi Publik Berbasis Web Responsive dapat dimanfaatkan sebagai media layananan administrasi publik pada desa yang ada pada suatu daerah. Sistem ini salah satu sistem yang berguna untuk memudahkan masyarakat desa dalam melakukan proses pelayanan administrasi kependudukan terutama bagi masyarakat yang ingin melakukan pelayanan proses pembuatan surat pengantar digital diantaranya surat pengantar Permohonan KTP WNI, Permohonan KK Baru WNI, Surat Keterangan Lahir, Surat Keterangan Menikah, Surat Pengantar SKCK, Surat Keterangan Wali, Surat Keterangan Belum Pernah Menikah, Surat Keterangan Janda/Duda, Surat Keterangan Tidak Mampu, Surat Permohonan Akta Kelahiran dan Surat Permohonan Akta Kematian serta layanan administrasi lainnya. Dengan sistem ini pemerintah dapat memantau pertumbuhan penduduk yang terjadi di desa melalui sistem ini. Dan sistem ini juga dapat turut berkontribusi dalam pelayanan administrasi kependudukan nasional. Metode penelitian yang digunakan yaitu system development life cycle (SDLC). Tahapan utamanya dapat terdiri dari tahapan perencanaan sistem (systems planning), analisis sistem (systems analysis), desain sistem (system design), seleksi sistem (system selection), implementasi sistem (systems implementation) dan perawatan sistem (systems maintenance) (Hidayatulloh \& Mulyadi, 2015).

Dengan ini peneliti membuat Sistem Pelayanan Administrasi Publik Berbasis Web Responsive. Adanya Sistem ini masyarakat desa dapat mengakses informasi kebutuhan administrasi kependudukan dan mencetak surat pengantar digital yang telah diverifikasi atau divalidasi oleh pemerintah pedesaan yang bisa disebut operator desa secara real time. Sedangkan untuk masyarakat umum dapat juga mengakses informasi tentang layanan administrasi publik yang dapat dilakukan pada pemerintahan desa. 


\section{A. Rumusan Masalah}

Dari uraian latar belakang di atas, maka rumusan masalahnya adalah :

a. Waktu pelayanan yang sangat panjang sehingga masyarakat terkadang harus menunggu beberapa hari karena kepala desa tidak berada di tempat.

b. Prosedur/birokrasi terkadang berbelit-belit dan belum jelas, sehingga membingungkan masyarakat desa

c. Rentan terjadinya pungutan liar yang dilakukan oleh oknum yang seharusnya masyarakat mendapatkan pelayanan tersebut secara gratis

\section{B. Tujuan Penelitian}

Adapun tujuan penelitian yang dilakukan untuk :

a. Meminimalisir terjadinya pungutan liar yang seharusnya penduduk mendapatkan pelayanan tersebut secara gratis

b. Memangkas waktu pelayanan yang sangat panjang sehingga penduduk tidak harus menunggu beberapa hari walaupun kepala desa tidak berada di tempat.

c. Menemukan Prosedur/birokrasi agar tidak berbelitbelit dan makin jelas, sehingga tidak membingungkan penduduk

\section{Kerangka Berfikir}

Dalam penelitian ini, penulis akan mencoba menerapkan layanan digital dalam pengurusan administrasi publik di pedesaan disebuah kabupaten. Dalam pelaksanaan untuk mengoptimalkan Penerapan aplikasi dalam penelitian ini akan diuji cobakan pada tingkat Kecamatan. Penerapan teknologi aplikasi berbasis responsive web design juga dimanfaatkan untuk penyampaikan informasi ke pusat sehingga data kependudukan yang ada di kabupaten dapat diperoleh dengan cepat dan tepat.

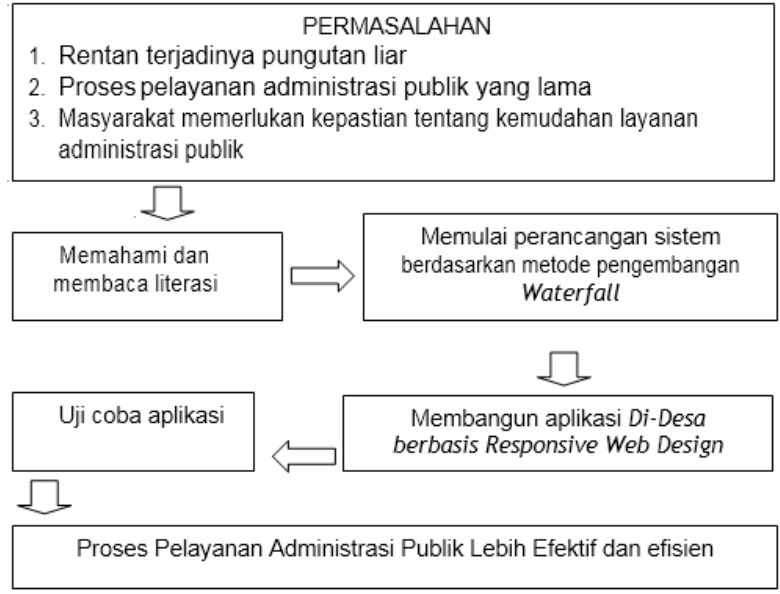

Gambar 1. Kerangka Berfikir

\section{Metodologi Penelitian}

1. Teknik Pengumpulan Data

Pada penelitian dalam pengumpulan data yang diterapkan adalah sebagai berikut :

a. Pengamatan Langsung
Penulis melakukan pengamatan langsung pada objek penelitian guna untuk mendapatkan data sehingga didapat gambaran proses pelayanan publik.

b. Wawancara

Untuk mendapatkan informasi secara lengkap dilakukan wawancara kesetiap bagian yang berhubungan dengan objek penelitian yang dilakukan

c. Studi Pustaka

Selain melakukan pengamatan langsung dan wawancara, peneliti juga melakukan studi litelature, sebagai bahan refrensi dalam melakukan penelitian.

2. Metode Pengembangan Sistem

Peneliti ini menggunakan metode pengembangan sistem yaitu system development life cycle (SDLC).

Tahapan utamanya dapat terdiri dari :

a. Tahapan perencanaan sistem (systems planning)

Pada tahap ini dilakukan pengumpulan data yang dibutuhkan dalam penelitian

b. Analisis sistem (systems analysis)

Pada tahapan ini dilakukan analisis kebutuhan sistem yang akan dikembangkan dan yang akan diimplementasikan

c. Desain sistem (system design)

Pada tahapan ini dilakukan desain perangkat lunak, perancangan struktur data, desain antar muka sistem.

d. Pembuatan Kode Program

Pada tahapan ini dilakukan penuangan desain kedalam bentuk program perangkat lunak, hasil pada tahap ini adalah perangkat lunak sesuai dengan desain sistem.

e. Pengujian sistem (systems testing)

Pada tahapan ini dilakukan pengujian perangkat lunak yang telah dihasilkan pada tahapan sebelumnya.

f. Perawatan sistem (systems maintenance)

Pada tahapan ini dilakukan perawatan terhadap sistem yang telah di hasilkan pada tahapan sebelumnya, hal tersebut dilakukan setelah dilakukan pemakaian sistem, hal tersebut dilakukan berdasarkan evaluasi selama pemakaian sistem.

\section{Pembahasan}

\section{A. Analisis Sistem}

Analisis kebutuhan informasi dilakukan dengan cara melihat langsung proses kepengurusan administrasi public di Desa. Hasil yang diperoleh dapat disimpulkan bahwa proses dilakukan masih manual, pemohon datang langsung kekantor desa, dari proses tersebut diperoleh akibat yang sangat siknifikan yaitu

a. Rentan terjadinya pungutan liar yang seharusnya penduduk mendapatkan pelayanan tersebut secara gratis

b. Waktu pelayanan yang sangat panjang sehingga penduduk terkadang harus menunggu beberapa hari karena kepala desa tidak berada di tempat.

c. Prosedur/birokrasi terkadang berbelit-belit dan belum jelas, sehingga membingungkan penduduk. 


\section{B. Perancangan Sistem}

1. Data Flow Diagram (DFD) Level 0

Dalam pembuatan DFD diawali dengan menggunakan DFD Level 0, atau yang sering disebut context diagram. Dalam dfd level 0 ini menggambarkan sistem secara keseluruhan dalam aplikasi pelayanan publik di-desa berbasis web responsive, secara umum dengan hubungan input, output dengan entitas luar.

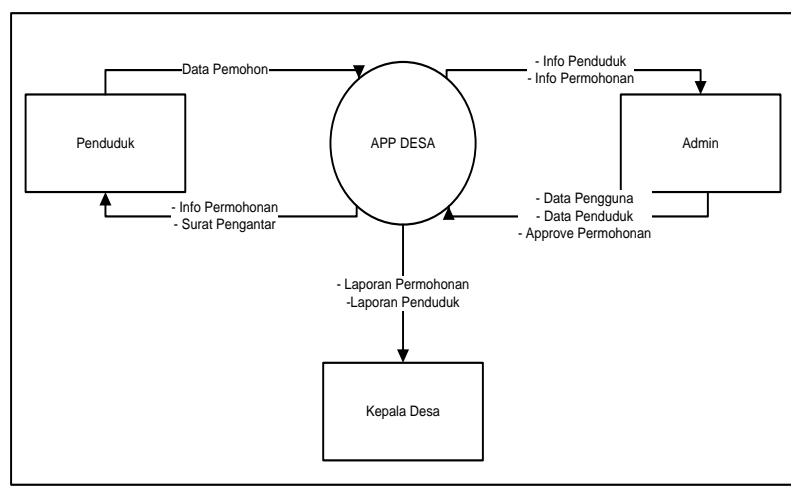

Gambar 2. DFD Level 0 Sistem Yang Diusulkan

Dari gambar di atas, dapat dijelaskan bahwa terdapat 3 entitas yang saling berhubungan, diantaranya, entitas admin, pemohon dan kepala desa, admin memberikan data pengguna, approve permohonan dan menerima info pemohon, dan info permohonan. Pemohon memberikan data pemohon, data permohonan, menerima info permohonan dan cetak surat pengantar. Kepala desa menerima laporan permohon dan permohonan.

a. DFD Level 1

Pada DFD Level 1 merupakan hasil dari DFD Level 0 yang telah dibuat sebelumnya. DFD Level 1 digunakan untuk mengambarkan modul-modul proses pembuatan aplikasi yang akan dikembangkan.

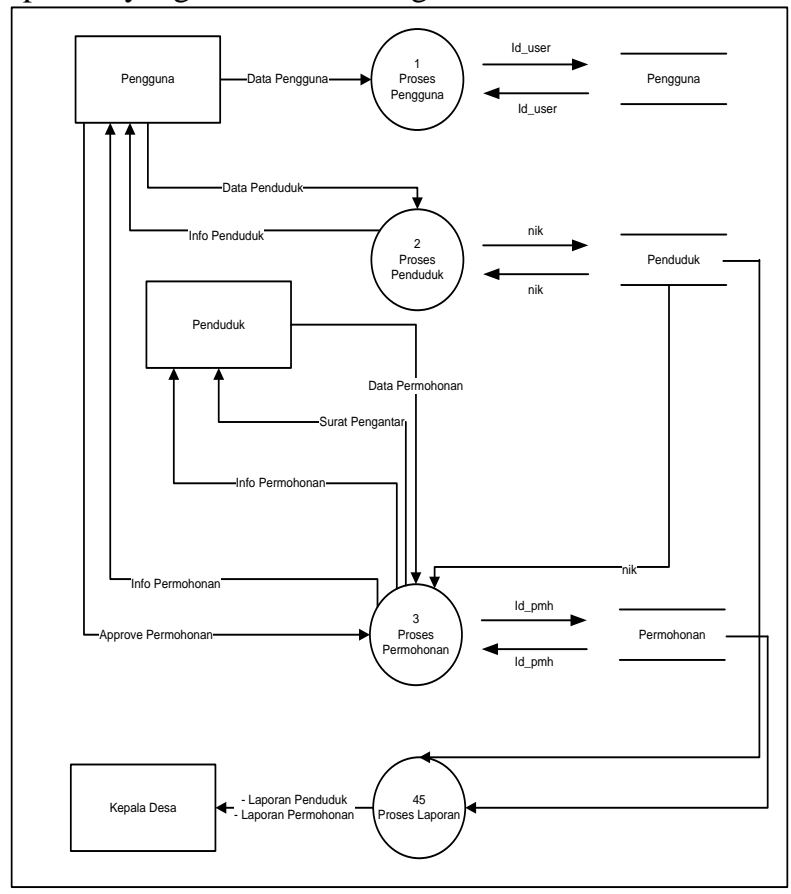

Gambar 3. DFD Level 1 b. Entity Relation Diagram (ERD)

Tabel yang ada pada aplikasi ini akan berelasi antara satu dengan lainnya, adapun dalam pembuatan relasi antar tabel pada aplikasi ini menggunakan ERD, seperti gambar 3 berikut :

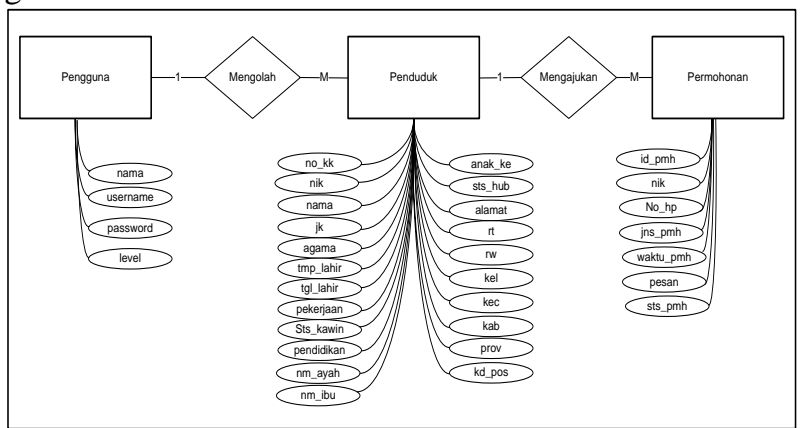

Gambar 4. Entity Relation Diagram (ERD)

c. Perancangan Tabel

Tabel 1. Tabel Pengguna

\begin{tabular}{|c|l|c|c|l|}
\hline No & \multicolumn{1}{|c|}{$\begin{array}{c}\text { Nama } \\
\text { Field }\end{array}$} & $\begin{array}{c}\text { Type } \\
\text { Data }\end{array}$ & $\begin{array}{c}\text { Ukur } \\
\text { an }\end{array}$ & \multicolumn{1}{|c|}{ Keterangan } \\
\hline 1. & id_user & int & 11 & Id pengguna \\
\hline 2. & nama & varchar & 50 & Nama pengguna \\
\hline 3. & username & varchar & 50 & Username \\
\hline 4. & password & varchar & 50 & Password \\
\hline 5. & level & varchar & 50 & level \\
\hline
\end{tabular}

Tabel 2. Tabel Peduduk

\begin{tabular}{|l|l|c|c|l|}
\hline No & \multicolumn{1}{|c|}{$\begin{array}{c}\text { Nama } \\
\text { Field }\end{array}$} & $\begin{array}{c}\text { Type } \\
\text { Data }\end{array}$ & $\begin{array}{c}\text { Ukur } \\
\text { an }\end{array}$ & Keterangan \\
\hline 1. & no_kk & int & 16 & $\begin{array}{l}\text { Nomor Kartu } \\
\text { Keluarga }\end{array}$ \\
\hline 2. & nik & int & 16 & $\begin{array}{l}\text { Nomor Induk } \\
\text { Kependudukan }\end{array}$ \\
\hline 3. & nama & varchar & 50 & Nama \\
\hline 4. & jk & varchar & 20 & Jenis kelamin \\
\hline 5. & agama & varchar & 16 & Agama \\
\hline 6. & tmp_lahir & Varchar & 16 & Tempat Lahir \\
\hline 7. & tgl_lahir & Int & 15 & Tanggal Lahir \\
\hline 8. & pekerjaan & Varchar & 20 & Pekerjaan \\
\hline 9. & sts_kawin & Varchar & 15 & $\begin{array}{l}\text { Status } \\
\text { Perkawinan }\end{array}$ \\
\hline 10. & pendidikan & Varchar & 15 & Pendidikan \\
\hline 11. & nm_ayah & Varchar & 50 & Nama Ayah \\
\hline 12. & nm_ibu & Varchar & 50 & Nama Ibu \\
\hline 13. & anak_ke & Int & 3 & Anak Ke \\
\hline 14. & alamat & Varchar & 100 & Alamat \\
\hline 15. & rt & Int & 3 & RT \\
\hline 16. & rw & Int & 3 & RW \\
\hline 17. & kel & Varchar & 20 & Kelurahan \\
\hline 18. & kec & Varchar & 20 & Kecamatan \\
\hline 19. & prov & varchar & 20 & Provinsi \\
\hline 20 & kd_pos & int & 7 & Kode Pos \\
\hline & & & \\
\hline
\end{tabular}

Tabel 3. Tabel Permohonan

\begin{tabular}{|c|l|c|c|l|}
\hline No & Nama Field & $\begin{array}{c}\text { Type } \\
\text { Data }\end{array}$ & Ukuran & Keterangan \\
\hline 1. & Id_pmh & int & 11 & $\begin{array}{l}\text { Id } \\
\text { permohonan }\end{array}$ \\
\hline 2. & nik & int & 16 & $\begin{array}{l}\text { Nomor Induk } \\
\text { Kependudukan }\end{array}$ \\
\hline 3. & no_hp & int & 12 & Nomor HP \\
\hline
\end{tabular}




\begin{tabular}{|c|l|l|c|l|}
\hline 4. & jns_pmh & varchar & 50 & $\begin{array}{l}\text { Jenis } \\
\text { permohonan }\end{array}$ \\
\hline 5. & waktu_pmh & $\begin{array}{l}\text { datetim } \\
\text { e }\end{array}$ & 12 & $\begin{array}{l}\text { Waktu } \\
\text { permohonan }\end{array}$ \\
\hline 6. & pesan & varchar & 50 & Pesan \\
\hline 7. & sts_pmh & varchar & 25 & $\begin{array}{l}\text { Status } \\
\text { permohonan }\end{array}$ \\
\hline
\end{tabular}

\section{Implementasi Sistem}

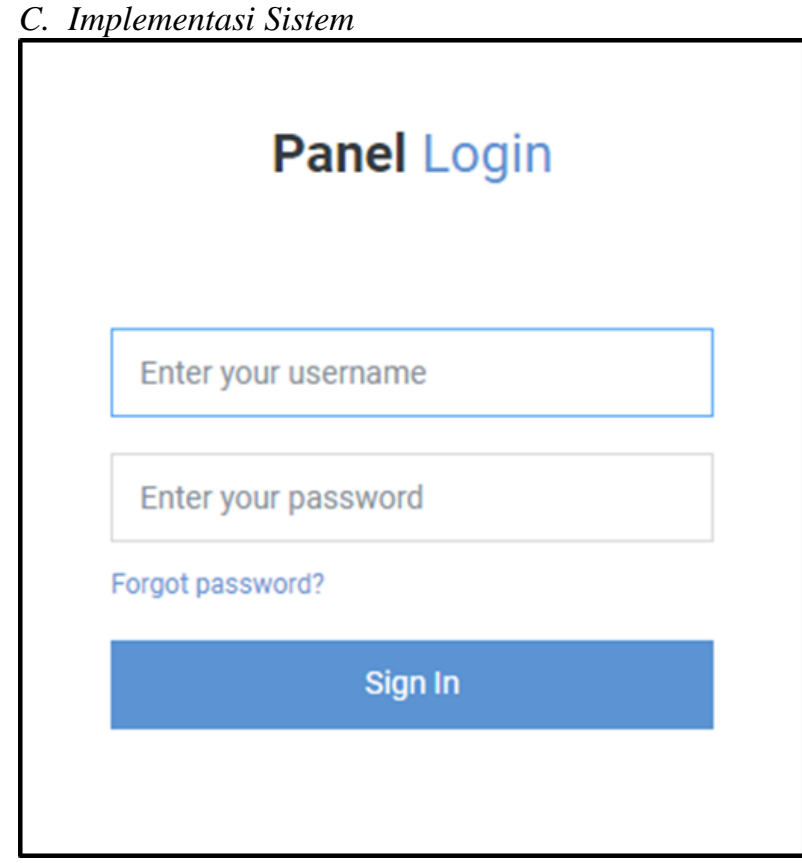

Gambar 5. Login System

Pada gambar 5 proses login hanya dapat dilakukan oleh penduduk yang bertempat tinggal didesa setempat dan operator desa, hak akses penduduk ini sudah didata oleh pemerintahan desa atau operator desa untuk dapat menggunakan sistem informasi digital pelayanan administrasi publik.

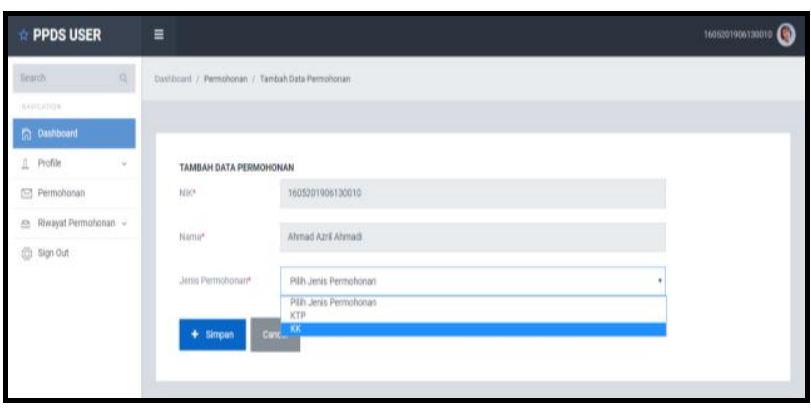

Gambar 6. Halaman Permohonan

Pada Gambar 6 merupakan bentuk form permohonan yang dapat digunakan masyarakat untuk mendapatkan surat pengantar secara digital dimana pemohon atau masyarakat dapat mengajukan permohonan melalu menu permohonan sesuai dengan permohonan yang diinginkan kemudian permohonan tersebut divalidasi oleh operator pemerintahan desa untuk diteruskan ke kepala desa melalui sistem dan kepala desa dapat meverifikasi permohonan yang masuk untuk dapat diproses pencetakan surat pengantar oleh pemohon sesuai dengan surat pengantar yang diusulkan.

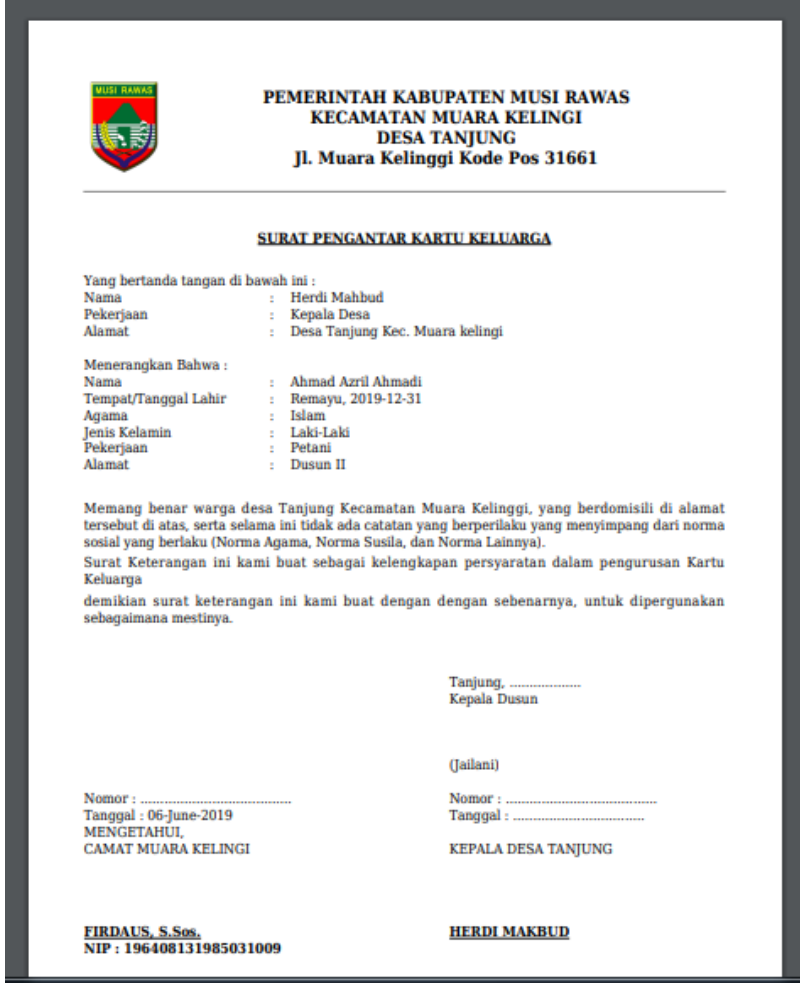

Gambar 7. Contoh Surat Pengantar Digital PDF

Gambar 7 adalah salah satu bentuk surat pengantar yang dicetak secara digital, file yang didapat oleh pemohon dalam bentuk file pdf.

\section{Kesimpulan}

Dari hasil penelitian ini dapat disimpulkan bahwa dihasilkan sebuah sistem informasi digital pelayanan administrasi publik di Desa berbasis web responsive. Sistem atau aplikasi yang dihasilkan dapat membantu memudahkan masyarakat desa dalam melakukan proses pelayanan administrasi kependudukan terutama bagi masyarakat yang ingin melakukan pelayanan proses pembuatan surat pengantar secara digital diantaranya Permohonan KTP WNI, Permohonan KK Baru WNI, Surat Keterangan Lahir, Surat Keterangan Menikah, Surat Pengantar SKCK, Surat Keterangan Wali, Surat Keterangan Belum Pernah Menikah, Surat Keterangan Janda/Duda, Surat Keterangan Tidak Mampu, Surat Permohonan Akta Kelahiran dan Surat Permohonan Akta Kematian. Selain itu aplikasi atau sistem dibangun sesuai dengan kebutuhan pemerintah Desa Tanjung Kecamatan Muara Kelingi Kabupaten Musi Rawas dalam upaya peningkatan mutu layanan publik bagi masyarakat Desa Desa Tanjung Kecamatan Muara Kelingi Kabupaten Musi Rawas.

Dari hasil penelitian yang telah dilakukan diharapkan penelitian tersebut dapat ditingkatkan ke pengarsipan dokumen persyaratan permohonan secara digitalisasi untuk menghindari penumpukan dokumen. 


\section{Daftar Pustaka}

Alandari, F. 2013. Peran Sistem Informasi Manajemen Berbasis Komputer Dalam Meningkatkan Pelayanan Publik Di Lingkungan, 1(1), 182-194.

Arsyad, L., \& Sodiq, A. 2014. Pelaksanaan Pelayanan Publik (Studi Kasus Administratif di Kantor Desa Kotabaru Seberida Kecamatan Keritang Kabupaten Indragiri Hilir). Lincolin Arsyad, 3(2), 1-46. https://doi.org/http://dx.doi.org/110.21043/equilibri um.v3i2.1268

Hendrianto, D. E. 2014. Pembuatan Sistem Informasi Perpustakaan Berbasis Website Pada Sekolah Menegah Pertama Negeri 1 Donorojo Kabupaten Pacitan. IJNS-Indonesian Journal on Networking and Security ISSN: 2302-5700 (Print) 2354-6654 (Online, 3(4), 2354-6654.

Hidayatulloh, S., \& Mulyadi, C. 2015. Sistem Pelayanan Administrasi Kependudukan Desa Candigatak Berbasis Web. Jurnal IT CIDA, 1(1), 42-55.

Novianty, C. 2017. Review Konsep Responsive Design Dengan Framework Materialize Pada Website. InfoTekJar (Jurnal Nasional Informatika Dan Teknologi Jaringan), 2(1), 41-44. https://doi.org/10.30743/infotekjar.v2i1.140

Nurmanina, A., Riska, \& Harihanto. 2013. Jurnal (1107-13-09-58-07). EJournal Sosiatri-Sosiologi, Vol. 1, pp. 37-49.

Sari, I. L. 2016. Penyelenggaraan Pelayanan Pembuatan Akta Pencatatan Sipil Kota Samarinda. 4(2), 27112725.

Sugiyarto, F., \& Irawan, C. 2013. Desain Sistem Informasi Pelayanan Pensiun pada PT.Asabri Kancab Semarang. Techno.COM, 12(1), 16-28.

Tofik, I. G., \& Hartawan, G. P. 2017. Perancangan Aplikasi. Jurnal Ilmiah Ilmu Ekonomi, 5(10), 139151.

Wijaya, Z. S. 2015. Pada Aplikasi Monitoring Keuangan Dan Aset ( Terkait Penatausahaan Piutang Tuntutan Ganti Kerugian Negara ). Jurnal Ekonomi Akutansi Dan Manajemen, 14 (1), 1-10. 